Article

\title{
Sterepinic Acids A-C, New Carboxylic Acids Produced by a Marine Alga-Derived Fungus
}

\author{
Takeshi Yamada * (D), Miwa Matsuda, Mayuko Seki, Megumi Hirose and Takashi Kikuchi \\ Osaka University of Pharmaceutical Sciences, 4-20-1, Nasahara, Takatsuki, Osaka 569-1094, Japan; \\ e12643@gap.oups.ac.jp (M.M.); e10118@gap.oups.ac.jp (M.S.); e11729@gap.oups.ac.jp (M.H.); \\ t.kikuchi@gly.oups.ac.jp (T.K.) \\ * Correspondence: yamada@gly.oups.ac.jp; Tel./FAX: +81-726-90-1085
}

Academic Editor: Isabel C. F. R. Ferreira

Received: 15 May 2018; Accepted: 30 May 2018; Published: 1 June 2018

\begin{abstract}
Sterepinic acids A-C (1-3), new carboxylic acids with two primary alcohols, have been isolated from a fungal strain of Stereum sp. OUPS-124D-1 attached to the marine alga Undaria pinnatifida. Dihydro-1,5-secovibralactone (4), a new vibralactone derivative, was isolated from the same fungal metabolites together with known vibralactone A (5), and 1,5-secovibralactone (6). The planar structures of these compounds have been elucidated by spectroscopic analyses using IR, HRFABMS, and NMR spectra. To determine the absolute configuration of the compounds, we used the phenylglycine methyl ester (PGME) method. These compounds exhibited less activity in the cytotoxicity assay against cancer cell lines.
\end{abstract}

Keywords: sterepinic acids; Stereum sp.; marine microorganism; Undaria pinnatifida; vibralactones; phenylglycine methyl ester method

\section{Introduction}

Our ongoing search for seeds of antitumor chemotherapy agents from marine microorganisms has led to the isolation of several antitumor and/or cytotoxic compounds [1-8]. In particular, we focused on the bioactive compounds with small molecular weight due to their advantages, such as easy synthesis and modification for increasing the activity. In addition, the synthesis of small bioactive compounds establishes a hypothetical biosynthesis mechanism of larger bioactive compounds. In this study, we isolated four new carboxylic acids with two primary alcohols, designated as sterepinic acids A-C (1-3) and dihydro-1,5-secovibralactone (4), together with the known vibralactone A (5) and 1,5-secovibralactone (6), from a strain of Stereum sp. OUPS-124D-1 derived from the marine alga Undaria pinnatifida. 5 was reported by Liu et al. [9], and many studies then followed this work, isolating the derivatives of 5 including 6 [10-15]. We report the determination of the absolute configurations of 1-4 by applying the phenylglycine methyl ester (PGME) method [16]. In addition, we report on the investigation of the cytotoxicity of these compounds against several cancer cell lines.

\section{Results}

Stereum sp., a microorganism from U. pinnatifida, was cultured at $27^{\circ} \mathrm{C}$ for 5 weeks in a medium $(50 \mathrm{~L})$ containing $1 \%$ glucose, $1 \%$ malt extract, and $0.05 \%$ peptone in artificial seawater adjusted to $\mathrm{pH}$ 7.6. After the incubation, the culture was filtrated through DIAION HP-20, and its $\mathrm{MeOH}$ elution was purified employing a stepwise combination of silica gel column chromatography and reverse phase HPLC to afford sterepinic acids, A (1) $(64.8 \mathrm{mg}) ; \mathrm{B}(2)(13.3 \mathrm{mg}) ; \mathrm{C}$ (3) $(16.8 \mathrm{mg})$; and dihydro-1,5-secovibralactone (4) (12.4 mg), as a pale yellow oil, respectively (Figure 1). 
<smiles>CC=CC[C@H](C=C(C)C(=O)O)CCO</smiles>

1<smiles>[2H][C@@H](/C=C(\CCO)CO[C@H](C)[C@H](/C=C(/CO)CCO)C/C=C\[3H])CC=C(C)C</smiles><smiles>C/C=C\C[C@H]1C=C(CO)CCOC1=O</smiles><smiles>CC(C)=CC[C@]12C=C(CO)C[C@H]1OC2=O</smiles><smiles>CC(C)=CC[C@H]1C=C(CO)C=COC1=O</smiles>

Figure 1. Structures of sterepinic acids A-C (1-3), dihydro-1,5-secovibralactone (4), and known compounds 5 and 6 .

The molecular formula of sterepinic acid A (1) has been determined as $\mathrm{C}_{12} \mathrm{H}_{20} \mathrm{O}_{4}$ from its molecular weight of $229.1443[\mathrm{M}+\mathrm{H}]^{+}$in HRFABMS. Its IR spectrum exhibited bands at 3330 and $1710 \mathrm{~cm}^{-1}$, that are characteristics of hydroxy and carbonyl groups, respectively. An analysis of the ${ }^{1} \mathrm{H}$ and ${ }^{13} \mathrm{C}$ NMR spectra of 1 (Table 1 and Table S1), using DEPT and ${ }^{1} \mathrm{H}-{ }^{13} \mathrm{C}$ heteronuclear multiple quantum coherence spectroscopy (HMQC), showed the presence of two olefin methyls (C-11 and C-12); four $\mathrm{sp}^{3}$-hybridized methylenes (C-5, C-6, C-7, and C-8), including two oxygen-bearing sp ${ }^{3}$-methylenes (C-6 and C-7); one $\mathrm{sp}^{3}$-methine (C-2); two $\mathrm{sp}^{2}$-methines (C-3 and C-9); two quaternary sp ${ }^{2}$-carbons (C-4 and C-10); and one carbonyl group (C-1). In the ${ }^{1} \mathrm{H}-{ }^{1} \mathrm{H}$ correlation spectroscopy (COSY) analysis, correlations were observed between $\mathrm{H}-5$ and H-6; H-2 and H-3; and H-2 and H-8, as shown by the bold lines in Figure 2. In the HMBC spectrum (Figure 2), the correlations from $\mathrm{H}-11$ and $\mathrm{H}-12$ to C-9 and C-10; from H-2 to C-1 and C-4; from H-3 to C-1, C-5, and C-7; from H-5 to C-3; from H-6 to C-4; from H-7 to C-3, C-4, and C-5; from H-8 to C-1 and C-10; from H-6 to C-4; and from H-7 to C-4, and C-5 elucidated the planar structure of $\mathbf{1}$ as 6-hydroxy-4-(hydroxymethyl)-2-(3-methylbut-2-en-1-yl) hex-3-enoic acid. The elucidation of the absolute stereostructure of $\mathbf{1}$ is described below, together with those of 2-4. 
Table 1. ${ }^{1} \mathrm{H}$ and ${ }^{13} \mathrm{C}$ NMR spectral data for metabolites (1-3) in $\mathrm{CDCl}_{3}$.

\begin{tabular}{|c|c|c|c|c|c|c|c|c|c|c|c|c|}
\hline \multirow{3}{*}{$\begin{array}{c}\text { Position } \\
1\end{array}$} & \multicolumn{4}{|c|}{1} & \multicolumn{4}{|c|}{2} & \multicolumn{4}{|c|}{3} \\
\hline & \multicolumn{2}{|c|}{$\delta_{\mathrm{H}}{ }^{a}$} & \multicolumn{2}{|c|}{$\delta_{\mathrm{C}}$} & \multicolumn{2}{|c|}{$\delta_{\mathrm{H}}^{a}$} & \multicolumn{2}{|c|}{$\delta_{\mathrm{C}}$} & \multicolumn{2}{|r|}{$\delta_{\mathrm{H}}^{a}$} & \multicolumn{2}{|c|}{$\delta_{\mathrm{C}}$} \\
\hline & & & 177.5 & (s) & & & 173.5 & (s) & & & 174.3 & (s) \\
\hline 2 & 3.27 & $\mathrm{~m}$ & 44.9 & (d) & 3.28 & $\mathrm{~m}$ & 45.4 & (d) & 3.28 & $\mathrm{~m}$ & 44.9 & (d) \\
\hline 3 & 5.50 & $\mathrm{~d}(10.2)$ & 127.0 & (d) & 5.49 & $\mathrm{~d}(10.8)$ & 129.3 & (d) & 5.55 & $\mathrm{~d}(9.6)$ & 129.3 & (d) \\
\hline 4 & & & 138.7 & (s) & & & 133.9 & (s) & & & 137.9 & (s) \\
\hline $5 \mathrm{~A}$ & 2.25 & $\mathrm{~m}$ & 31.9 & $(\mathrm{t})$ & 2.18 & $\mathrm{~m}$ & 32.3 & $(\mathrm{t})$ & 2.30 & ddd $(14.4,5.4,5.4)$ & 27.7 & $(\mathrm{t})$ \\
\hline $5 \mathrm{~B}$ & 2.49 & $\mathrm{~m}$ & & & 2.54 & $\mathrm{~m}$ & & & 2.54 & ddd $(14.4,5.4,5.4)$ & & \\
\hline $6 \mathrm{~A}$ & 3.68 & br s & 61.0 & $(\mathrm{t})$ & 3.65 & br s & 61.4 & $(\mathrm{t})$ & 4.20 & $\mathrm{~m}$ & 63.5 & $(\mathrm{t})$ \\
\hline $6 \mathrm{~B}$ & & & 66.8 & $(\mathrm{t})$ & 3.72 & br s & & & & & & \\
\hline $7 \mathrm{~A}$ & 4.03 & br s & & & 4.05 & $\mathrm{~d}(13.2)$ & 67.9 & $(\mathrm{t})$ & 4.07 & $\mathrm{~m}$ & 66.5 & $(\mathrm{t})$ \\
\hline $7 \mathrm{~B}$ & & & & & & $\mathrm{~d}(13.2)$ & & & & & & \\
\hline $8 \mathrm{~A}$ & 2.20 & $\mathrm{~m}$ & 30.9 & $(\mathrm{t})$ & 2.20 & $\mathrm{~m}$ & $30.8^{b 5}$ & $(\mathrm{t})$ & 2.20 & $\mathrm{~m}$ & 31.4 & $(\mathrm{t})$ \\
\hline $8 \mathrm{~B}$ & 2.44 & $\mathrm{~m}$ & & & 2.46 & $\mathrm{~m}$ & & & 2.44 & $\mathrm{~m}$ & & \\
\hline 9 & 5.04 & $\mathrm{dd}$ & 120.2 & (d) & 5.03 & $\mathrm{~m}$ & $120.2^{b 6}$ & (d) & $5.02^{b 1}$ & $\mathrm{dd}(7.2,7.2)$ & $120.2^{b 2}$ & (d) \\
\hline 10 & & & 134.1 & (s) & & & $134.2^{b 7}$ & (s) & & & 134.3 & (s) \\
\hline 11 & 1.67 & $\mathrm{~s}$ & 25.7 & (q) & 1.67 & $\mathrm{~s}$ & 25.7 & (q) & 1.67 & $\mathrm{~s}$ & 25.7 & (q) \\
\hline 12 & 1.60 & $\mathrm{~s}$ & 17.8 & (q) & 1.60 & $\mathrm{~s}$ & 17.8 & (q) & $1.59^{b 3}$ & $\mathrm{~s}$ & $17.8^{b 4}$ & (q) \\
\hline $1^{\prime}$ & & & & & & & 173.5 & (s) & & & 174.3 & (s) \\
\hline $2^{\prime}$ & & & & & 3.28 & $\mathrm{~m}$ & 45.4 & (d) & 3.28 & $\mathrm{~m}$ & 44.9 & (d) \\
\hline $3^{\prime}$ & & & & & 5.52 & $\mathrm{~d}(10.8)$ & 127.2 & (d) & 5.51 & $\mathrm{~d}(9.6)$ & 127.2 & (d) \\
\hline $4^{\prime}$ & & & & & & & 139.6 & (s) & & & 138.7 & (s) \\
\hline $5^{\prime} \mathrm{A}$ & & & & & 2.29 & $\mathrm{~m}$ & 32.3 & $(\mathrm{t})$ & 2.25 & $\mathrm{~m}$ & 32.2 & $(\mathrm{t})$ \\
\hline $5^{\prime} \mathrm{B}$ & & & & & 2.54 & $\mathrm{~m}$ & & & 2.51 & $\mathrm{~m}$ & & \\
\hline $6^{\prime} \mathrm{A}$ & & & & & 3.72 & brs & 60.5 & $(\mathrm{t})$ & 3.65 & br s & 61.1 & $(\mathrm{t})$ \\
\hline $6^{\prime} \mathrm{B}$ & & & & & & & & & 3.71 & br s & & \\
\hline $7^{\prime}$ & & & & & 4.05 & br s & 67.5 & $(\mathrm{t})$ & 4.02 & $\mathrm{~m}$ & 67.4 & $(\mathrm{t})$ \\
\hline $8^{\prime} \mathrm{A}$ & & & & & 2.20 & $\mathrm{~m}$ & $30.6^{b 5}$ & $(\mathrm{t})$ & 2.20 & $\mathrm{~m}$ & 31.4 & $(\mathrm{t})$ \\
\hline $8^{\prime} \mathrm{B}$ & & & & & 2.46 & $\mathrm{~m}$ & & & 2.44 & $\mathrm{~m}$ & & \\
\hline $9^{\prime}$ & & & & & 5.03 & $\mathrm{~m}$ & $120.3^{b 6}$ & (d) & $5.06^{b 1}$ & $\mathrm{dd}(7.2,7.2)$ & $120.3^{b 2}$ & (d) \\
\hline $10^{\prime}$ & & & & & & & $134.3^{b 7}$ & (s) & & & 134.3 & (s) \\
\hline $11^{\prime}$ & & & & & 1.67 & $\mathrm{~s}$ & 25.7 & (q) & 1.67 & $\mathrm{~s}$ & 25.7 & (q) \\
\hline $12^{\prime}$ & & & & & 1.60 & $\mathrm{~s}$ & 17.8 & (q) & $1.61^{b 3}$ & $\mathrm{~s}$ & $17.9^{b 4}$ & (q) \\
\hline
\end{tabular}

${ }^{a}{ }^{1} \mathrm{H}$ chemical shift values $\left(\delta\right.$ ppm from $\left.\mathrm{SiMe}_{4}\right)$ followed by multiplicity. ${ }^{b 1-b 7}$ interchangeable. 


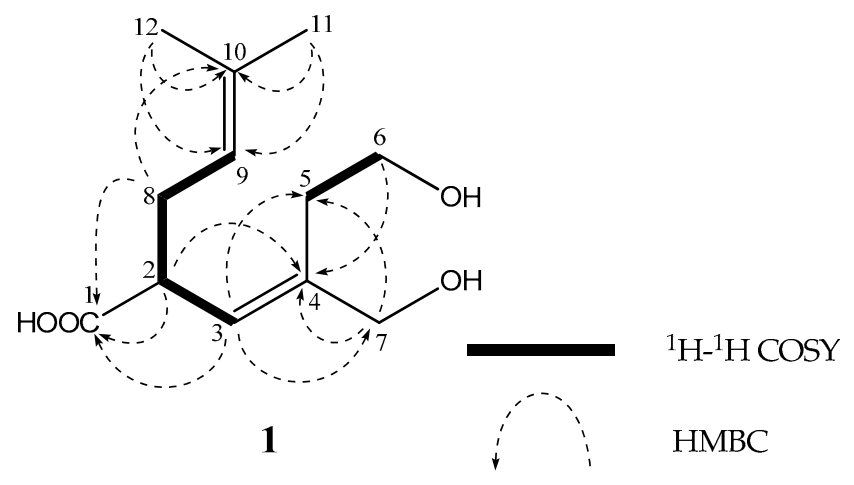

Figure 2. Selected ${ }^{1} \mathrm{H}-{ }^{1} \mathrm{H}$ COSY and HMBC correlations of $\mathbf{1}$.

Sterepinic acids, B (2) and C (3), were assigned the molecular formula of $\mathrm{C}_{24} \mathrm{H}_{38} \mathrm{O}_{7}$, with both compounds showing molecular weight almost twice as large as that of $\mathbf{1}$. While the general features of NMR spectra (Table 1, Tables S2 and S3) closely resembled those of $\mathbf{1}$, the ${ }^{1} \mathrm{H}$ and ${ }^{13} \mathrm{C}$ signals of $\mathbf{2}$ and $\mathbf{3}$ were observed in pairs or with the overlapping of two signals for each functional group (vide info.), except for the proton signal of the oxygen-bearing methylenes (C-7 $\left(\delta_{\mathrm{H}} 4.48 \mathrm{~d}\right.$, and $\left.\delta_{\mathrm{H}} 4.62 \mathrm{~d}\right)$ in 2$)$ and $\mathrm{C}-6\left(\delta_{\mathrm{H}} 4.20 \mathrm{~m}\right)$ in 3$)$. This phenomenon suggested that 2 and 3 were the dimers of $\mathbf{1}$. As expected, for the HMBC spectrum of $\mathbf{2}$ (Table S2), the correlations shown in Figure 3A were used to construct two carboxylic acids, both of which are identical to the planar structure of $\mathbf{1}$. In addition, the correlation from $\mathrm{H}-7$ in one carboxylic acid to $\mathrm{C}-\mathrm{1}^{\prime}$ in another carboxylic acid revealed that the two carboxylic acids were condensed to a dimer esterified between C-7 and C- $1^{\prime}$ (Figure 3A and Table S2). By contrast, the HMBC correlation from $\mathrm{H}-6$ to $\mathrm{C}-1^{\prime}$ observed in 3 demonstrated that the chemical structure of 3 was similar to that of the dimer esterified between C-6 and C-1' (Figure 3B and Table S3).

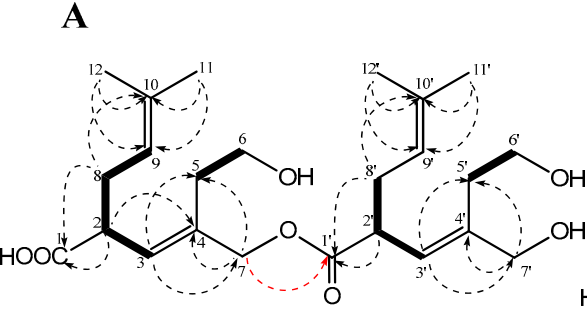

2

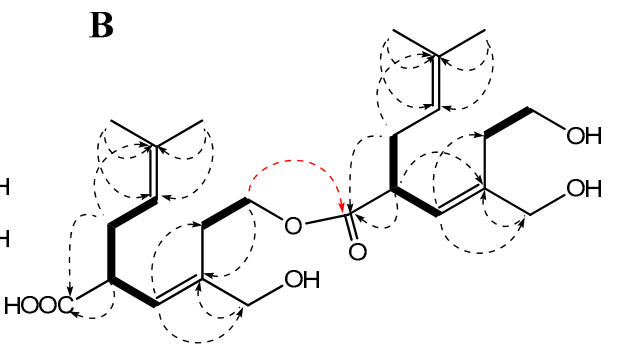

3

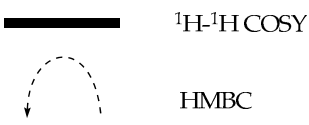

Figure 3. Selected ${ }^{1} \mathrm{H}-{ }^{1} \mathrm{H}$ COSY and $\mathrm{HMBC}$ correlations of $\mathbf{2}(\mathbf{A})$ and $\mathbf{3}$ (B).

Dihydro-1,5-secovibralactone (4) exhibited the molecular formula $\mathrm{C}_{12} \mathrm{H}_{20} \mathrm{O}_{4}$, containing two fewer hydrogen atoms, and one less oxygen atom than 1. Compared with the NMR spectra of 4 (Table 2 and Table S4), those of 1 showed large differences in the proton signals of $\mathrm{H}-1\left(\delta_{\mathrm{H}} 3.68 \mathrm{~m}\right)$ and $\mathrm{H}-5$ ( $\delta_{\mathrm{H}} 4.68 \mathrm{ddd}$ and $4.33 \mathrm{ddd}$ ), corresponding to $\mathrm{H}-2$ and $\mathrm{H}-6$ in 1 , respectively, and the carbon signals of $\mathrm{C}-1\left(\delta_{\mathrm{H}} 40.2\right), \mathrm{C}-2\left(\delta_{\mathrm{H}} 121.2\right)$, and C-7 $\left(\delta_{\mathrm{H}} 174.3\right)$, corresponding to C-2, C-3, and C-1, respectively, in 1 . The numbering of the carbon positions followed the numbering mentioned in a previous report [6]. 4 was observed to be the monomer with the same carboxylic acid unit as $\mathbf{1}$. In addition, HMBC correlations from H-5 to C-7 (Table S4 and Figure 4) elucidated the planar structure of 4 as a dihydro-isomer of 1,5-secovibralactone (6) [10]. 
Table 2. ${ }^{1} \mathrm{H}$ and ${ }^{13} \mathrm{C}$ NMR spectral data for metabolites 4 in $\mathrm{CDCl}_{3}$.

\begin{tabular}{|c|c|c|c|c|}
\hline \multirow{3}{*}{$\begin{array}{c}\text { Position } \\
1\end{array}$} & \multicolumn{4}{|c|}{4} \\
\hline & \multicolumn{2}{|r|}{$\delta_{\mathrm{H}}{ }^{a}$} & \multicolumn{2}{|c|}{$\delta_{\mathrm{C}}$} \\
\hline & 3.68 & $\mathrm{~m}$ & 40.2 & (d) \\
\hline 2 & 5.36 & br s & 121.2 & (d) \\
\hline 3 & & & 139.2 & (s) \\
\hline $4 \mathrm{~A}$ & 2.45 & br d (19.2) & 30.3 & $(\mathrm{t})$ \\
\hline $4 \mathrm{~B}$ & 2.59 & $\mathrm{~m}$ & & \\
\hline $5 \alpha$ & 4.68 & ddd $(12.6,12.6,1.8)$ & 64.4 & $(\mathrm{t})$ \\
\hline $5 \beta$ & 4.33 & ddd $(12.6,4.8,2.4)$ & & \\
\hline \multicolumn{5}{|l|}{6} \\
\hline 7 & & & 174.3 & (s) \\
\hline $8 \mathrm{~A}$ & 2.33 & ddd $(14.4,6.6,6.6)$ & 30.1 & $(\mathrm{t})$ \\
\hline $8 \mathrm{~B}$ & 2.52 & ddd $(14.4,6.6,6.6)$ & & \\
\hline 9 & 5.14 & dd $(6.6,6.6)$ & 120.9 & (d) \\
\hline 10 & & & 134.6 & (s) \\
\hline 11 & 1.72 & $\mathrm{~s}$ & 25.8 & (q) \\
\hline 12 & 1.67 & $\mathrm{~s}$ & 18.0 & (q) \\
\hline $13 \mathrm{~A}$ & 3.99 & $\mathrm{~d}(13.8)$ & 67.4 & $(\mathrm{t})$ \\
\hline $13 \mathrm{~B}$ & 4.01 & $\mathrm{~d}(13.8)$ & & \\
\hline
\end{tabular}

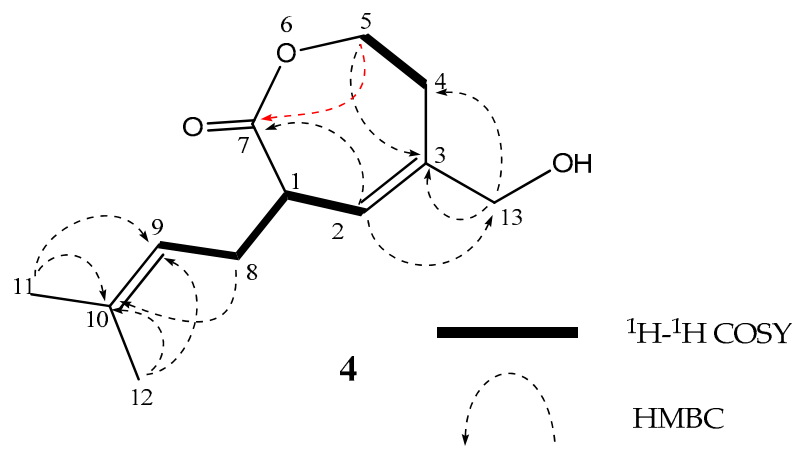

Figure 4. Selected ${ }^{1} \mathrm{H}-{ }^{1} \mathrm{H}$ COSY and HMBC correlations of 4.

For the determination of the absolute stereostructures of metabolites isolated in this study, we first examined the absolute configuration of $\mathbf{1}$, which is the common unit in all compounds of this study. 1 showed the presence of a secondary carboxy group at C-2, and we therefore used the PGME method [16]. The ${ }^{1} \mathrm{H}$ chemical-shift differences between the (S)- and (R)-PGME amides $\mathbf{1 a}$ and $\mathbf{1 b}$ revealed the $S$ configuration at C-2 (Figure 5).

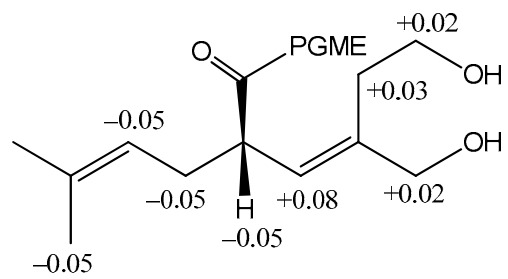

1a $\mathrm{R}=(S)-\mathrm{PGME}$ amide

1b $\mathrm{R}=(R)-\mathrm{PGME}$ amide

Figure 5. ${ }^{1} \mathrm{H}$ chemical-shift differences $(\Delta \delta$ ppm) between the $(S)$ - and $(R)$ - PGME amides $\mathbf{1 a}$ and $\mathbf{1 b}$. 
Next, for the elucidation of the stereochemistry of 2-4, we attempted to perform hydrolysis to derive 1 from 2-4; however, due to the small volume of reaction, the carboxylic acid was not produced. We therefore tried methanolysis to facilitate the purification of the product resulting from the reaction. The treatment with concd $\mathrm{H}_{2} \mathrm{SO}_{4}$ of $\mathrm{MeOH}$ solution of 2 only gave a methyl carboxylate, the spectral data $\left({ }^{1} \mathrm{H}\right.$ NMR spectrum and the optical rotation) for which were identical to those of the methyl ester of $\mathbf{1}$; i.e., 2 is found to be in the $2 S, 2^{\prime} S$ absolute configuration. The same procedure applied to 3 and 4 revealed the $S$ configuration at $C-2$ and $C-2^{\prime}$ in 3 , and the $S$ configuration at C-2 in 4, respectively. This evidence confirmed that $\mathbf{2}-\mathbf{4}$ were composed of $\mathbf{1}$. A lone pair on the alcohol oxygen atom attacks a carboxy carbon atom by an intra- or intermolecular nucleophilic reaction, as shown by the arrows coded using three different colors (Scheme 1). The routes shown in red and blue, which are the dimerization routes, produce 2 and 3, respectively. On the other hand, the route shown in black leads to 4 followed by a dehydrogenation to 6 . Meanwhile, Zhao et al., performed an in vitro enzymatic conversion, and verified biochemically the enzymatic production of 5 from 6 by the analyses of LC/MS/MS [17].

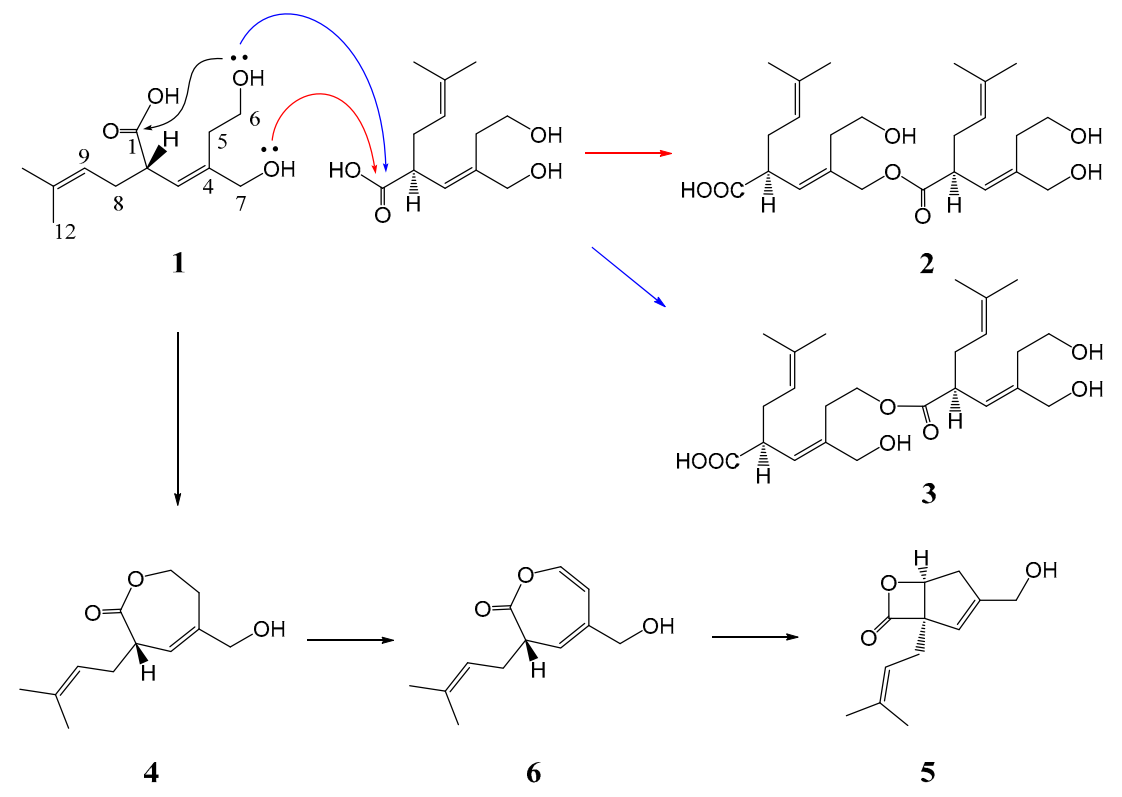

Scheme 1. Plausible mechanism for the formation of 2-6 from $\mathbf{1 .}$

Cancer cell growth-inhibitory properties of sterepinic acids A-C (1-3) and dihydro-1,5secovibralactone (4) were examined using murine P388 leukemia, human HL-60 leukemia, and murine L1210 leukemia cell lines; however, these metabolites did not exhibit significant activity against these cancer cells (Table 3). We therefore continue to investigate related compounds with more potent cytotoxicity from this fungal metabolite and examine another assay.

Table 3. Cytotoxicity assay against P388, HL-60, and L1210.

\begin{tabular}{|c|c|c|c|}
\hline Compounds & $\begin{array}{l}\text { Cell Line P388 } \\
\mathrm{IC}_{50}(\mu \mathrm{M})^{a}\end{array}$ & $\begin{array}{l}\text { Cell Line HL-60 } \\
\mathrm{IC}_{50}(\mu \mathrm{M})^{a}\end{array}$ & $\begin{array}{l}\text { Cell Line L1210 } \\
\mathrm{IC}_{50}(\mu \mathrm{M})^{a}\end{array}$ \\
\hline 1 & $>500$ & $>500$ & $>500$ \\
\hline 2 & $>500$ & 236.7 & $>500$ \\
\hline 3 & $>500$ & 60.2 & 480.9 \\
\hline 4 & $>500$ & 189.5 & $>500$ \\
\hline 5 -fluorouracil ${ }^{b}$ & 6 & 4.9 & 4.5 \\
\hline
\end{tabular}




\section{Materials and Methods}

\subsection{General Experimental Procedures}

NMR spectra were recorded on an Agilent-NMR-vnmrs (Agilent Technologies, Santa Clara, CA, USA) $600 \mathrm{MHz}$ and $400 \mathrm{MHz}$ with tetramethylsilane (TMS) as an internal reference. FABMS was recorded using a JEOL JMS-7000 mass spectrometer (JEOL, Tokyo, Japan). IR spectra was recorded on a JASCO FT/IR-680 Plus (Tokyo, Japan). Optical rotations were measured using a JASCO DIP-1000 digital polarimeter (Tokyo, Japan). DIAION HP20 (Mitsubishi Chemical, Tokyo, Japan), and Silica gel 60 (230-400 mesh, Nacalai Tesque, Inc. Kyoto, Japan) was used for column chromatography with medium pressure. ODS HPLC was run on a JASCO PU-1586 (Tokyo, Japan) equipped with a differential refractometer (RI-1531, Tokyo, Japan) and Cosmosil Packed Column 5C 18 -MSII (25 cm $\times 20$ mm i.d., Nacalai Tesque, Inc., Kyoto, Japan). Analytical TLC was performed on precoated Merck aluminum sheets (DC-Alufolien Kieselgel 60 F254, 0.2 mm, Merck, Darmstadt, Germany) with the solvent system $\mathrm{CH}_{2} \mathrm{Cl}_{2}-\mathrm{MeOH}$ (19:1), and compounds were viewed under a UV lamp (AS ONE Co., Ltd., Osaka, Japan) and sprayed with $10 \% \mathrm{H}_{2} \mathrm{SO}_{4}$ followed by heating.

\subsection{Fungal Material}

A strain of Stereum sp. was initially isolated from a piece of the marine alga Undaria pinnatifida collected at collected in Osaka bay, Japan in May 2015. The fungal strain was identified by Techno Suruga Laboratory Co., Ltd. The surface of the marine alga was wiped with EtOH, and its snip applied to the surface of nutrient agar layered in a Petri dish. Serial transfers of one of the resulting colonies provided a pure strain of Stereum sp.

\subsection{Culturing and Isolation of Metabolites}

The fungal strain was cultured at $27^{\circ} \mathrm{C}$ for 4 weeks in a liquid medium (50 L) containing $1 \%$ malt extract, $0.05 \%$ peptone, and $1 \%$ D-glucose in artificial seawater adjusted to $\mathrm{pH} 7.5$. The culture was filtered under suction, and the culture filtrate was passed through to DIAION HP20, and washed with water to remove water-soluble component. The fraction eluted with $\mathrm{MeOH}$ were evaporated in vacuo to afford a mixture of crude metabolites $(10.2 \mathrm{~g})$ that exhibited cytotoxicity against the P388 cell line $\left(\mathrm{IC}_{50}<10 \mu \mathrm{g} / \mathrm{mL}\right)$. The mixture was chromatographed on a silica gel column with a $\mathrm{CH}_{2} \mathrm{Cl}_{2}-\mathrm{MeOH}$ gradient as the eluent to afford Fraction (Fr.) 1 (2\% $\mathrm{MeOH}$ in $\mathrm{CHCl}_{3}$ eluate, $\left.270.5 \mathrm{mg}\right)$ and Fr. 2 (10\% $\mathrm{MeOH}$ in $\mathrm{CHCl}_{3}$ eluate, $\left.840.3 \mathrm{~g}\right)$. Fr. 1 was purified by ODS HPLC using $\mathrm{MeOH}-\mathrm{H}_{2} \mathrm{O}$ (50:50) as the eluent to afford $4(12.4 \mathrm{mg})$. Fr. 2 was purified by $\mathrm{HPLC}$ using $\mathrm{MeOH}-\mathrm{H}_{2} \mathrm{O}(60: 40)$ as the eluent to afford 2 (13.3 mg), 3 (16.8 mg), and Fr. 3 (102.3 mg). Fr. 3 was purified by ODS HPLC using $\mathrm{MeOH}-\mathrm{H}_{2} \mathrm{O}(40: 60)$ as the eluent to afford $1(64.8 \mathrm{mg})$.

Sterepinic acids A (1): Pale yellow oil; $[\alpha]_{\mathrm{D}}^{22}+58.0$ (c $\left.0.34, \mathrm{MeCN}\right)$; IR (neat) $v_{\max } / \mathrm{cm}^{-1}$ : 3330, 1710. FABMS $m / z$ (\%): 229 ([M + H] $\left.]^{+}, 71.4 \%\right), 211(87.4 \%), 143(34.2 \%), 69(100 \%)$. HRFABMS $m / z 229.1443[\mathrm{M}+\mathrm{Na}]^{+}\left(\right.$calcd for $\left.\mathrm{C}_{12} \mathrm{H}_{21} \mathrm{O}_{4}: 229.1440\right) .{ }^{1} \mathrm{H}$ and ${ }^{13} \mathrm{C}$ NMR data are listed in Table 1 and Table S1 (SI).

Sterepinic acids B (2): Pale yellow oil; $[\alpha]_{\mathrm{D}}^{22}+141.7$ (c $\left.0.27, \mathrm{MeCN}\right)$; IR (neat) $v_{\max } / \mathrm{cm}^{-1}$ : 3362, 1730. FABMS $m / z(\%): 439$ ([M + H] $\left.]^{+}, 40.9 \%\right), 211(93.5 \%), 69$ (100\%). HRFABMS $m / z 439.2694$ $[\mathrm{M}+\mathrm{H}]^{+}$(calcd for $\left.\mathrm{C}_{24} \mathrm{H}_{39} \mathrm{O}_{7}: 439.2695\right) .{ }^{1} \mathrm{H}$ and ${ }^{13} \mathrm{C}$ NMR data are listed in Table 1 and Table S2 (SI).

Sterepinic acids C (3): Pale yellow oil; $[\alpha]_{\mathrm{D}}^{22}+53.5$ (c $\left.0.16, \mathrm{MeCN}\right)$; IR (neat) $v_{\max } / \mathrm{cm}^{-1}: 3383$, 1710. FABMS $m / z(\%): 439\left([\mathrm{M}+\mathrm{H}]^{+}, 15.9 \%\right), 211(54.0 \%), 69(96.1 \%)$. HRFABMS $m / z 439.2694$ $[\mathrm{M}+\mathrm{H}]^{+}$(calcd for $\left.\mathrm{C}_{24} \mathrm{H}_{39} \mathrm{O}_{7}: 439.2695\right) .{ }^{1} \mathrm{H}$ and ${ }^{13} \mathrm{C}$ NMR data are listed in Table 1 and Table S3 (SI).

Dihydro-1,5-secovibralactone (4): Pale yellow oil; $[\alpha]_{\mathrm{D}}^{22}+7.9(c 0.32, \mathrm{MeCN})$; IR (neat) $v_{\max } / \mathrm{cm}^{-1}$ : 3396, 1736. FABMS $m / z$ (\%): $211\left([\mathrm{M}+\mathrm{H}]^{+}, 100 \%\right) 142(37.7 \%), 69$ (54.1\%. HRFABMS $m / z 211.1342$ $[\mathrm{M}+\mathrm{H}]^{+}$(calcd for $\left.\mathrm{C}_{12} \mathrm{H}_{19} \mathrm{O}_{3}: 211.1334\right) .{ }^{1} \mathrm{H}$ and ${ }^{13} \mathrm{C}$ NMR data are listed in Table 1 and Table S3 (SI). 


\subsection{Chemical Transformation}

\subsubsection{Formation of the (S)- and (R)-PGME Amides}

To a solution of $1(5.8 \mathrm{mg}, 0.025 \mathrm{mmol})$ and $(S)$-PGME $(0.054 \mathrm{mmol})$ in dry DMF $(1 \mathrm{~mL})$ was added to $\mathrm{EDC}-\mathrm{HCl}(0.050 \mathrm{mmol}), \mathrm{HOBt}(0.050 \mathrm{mmol})$, and DMAP (catalysis volume). The reaction mixture was stirred at room temperature 2 hours. Water $(1.0 \mathrm{~mL})$ was added to the reaction mixture, and then extracted using $\mathrm{CH}_{2} \mathrm{Cl}_{2}$. The organic layer was evaporated under reduced pressure, and the residue was purified by HPLC using $\mathrm{MeOH}-\mathrm{H}_{2} \mathrm{O}$ (50:50) as the eluent to afford (S)-PGME amide $1 \mathrm{a}(0.9 \mathrm{mg}$, $0.0024 \mathrm{mmol}$ ) as a pale yellow oil.

$1(6.7 \mathrm{mg}, 0.030 \mathrm{mmol})$ and $(R)$-PGME $(0.052 \mathrm{mmol})$ were treated with the same procedure to afford $(R)$-PGME amide $\mathbf{2 a}(3.1 \mathrm{mg}, 0.0083 \mathrm{mmol})$ as a pale yellow oil.

PGME amide 1a: Pale yellow oil; HRFABMS $m / z 376.2126[\mathrm{M}+\mathrm{H}]^{+}$(calcd for $\mathrm{C}_{21} \mathrm{H}_{30} \mathrm{NO}_{5}$ : 376.2124). ${ }^{1} \mathrm{H}$ NMR $\delta$ ppm (400 MHz in $\left.\mathrm{CDCl}_{3}\right): 1.61(3 \mathrm{H}, \mathrm{s}, \mathrm{H}-11), 2.16(1 \mathrm{H}, \mathrm{ddd}, J 17.2,7.6,7.6 \mathrm{~Hz}$, H-8A), 2.25 (1H, ddd, J 14.8, 6.0, 6.0 Hz, H-5A), 2.47 (1H, ddd, J 17.2, 7.6, 7.6 Hz, H-8B), 2.60 (1H, ddd, J 14.8, 7.6, 7.6 Hz, H-5B), $3.22(1 \mathrm{H}, \mathrm{ddd}, J$ 10.4, 7.6, $7.6 \mathrm{~Hz}, \mathrm{H}-2), 3.68\left(3 \mathrm{H}, \mathrm{s}, \mathrm{OCH}_{3}\right), 3.79(2 \mathrm{H}, \mathrm{m}, \mathrm{H}-6)$, $4.07(1 \mathrm{H}, \mathrm{d}, J 17.6 \mathrm{~Hz}, \mathrm{H}-7 \mathrm{~A}), 4.11(1 \mathrm{H}, \mathrm{d}, J 17.6 \mathrm{~Hz}, \mathrm{H}-7 \mathrm{~B}), 4.99(1 \mathrm{H}, \mathrm{dd}, J$ 7.6, $7.6 \mathrm{~Hz}, \mathrm{H}-9), 5.54,(1 \mathrm{H}, \mathrm{d}$, J 8.0 Hz, Gly-CH), 5.60 (1H, d, J 10.4 Hz, H-3), 7.24-7.34 (5H, m, Ar.H).

PGME amide 1b: Pale yellow oil; HRFABMS $m / z 376.2126[\mathrm{M}+\mathrm{H}]^{+}$(calcd for $\mathrm{C}_{21} \mathrm{H}_{30} \mathrm{NO}_{5}$ : 376.2124). ${ }^{1} \mathrm{H}$ NMR $\delta$ ppm (400 MHz in $\left.\mathrm{CDCl}_{3}\right): 1.58$ (3H, s, H-12), 1.64 (3H, s, H-11), 2.21 (1H, ddd, J 17.2, 7.6, 7.6 Hz, H-8A), 2.30 (1H, ddd, J 10.8, 5.6, 4.0 Hz, H-5A), 2.51 (1H, ddd, J 17.2, 7.6, 7.6 Hz,

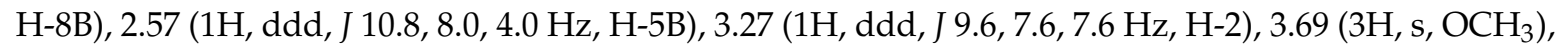
3.77 (2H, m, H-6), 4.05 (1H, m, H-7A), 4.09 (1H, m, H-7B), 5.03 (1H, dd, J 7.6, 7.6 Hz, H-9), 5.54, (1H, d, J $8.0 \mathrm{~Hz}, \mathrm{Gly}-\mathrm{CH}), 5.52$ (1H, d, J $9.6 \mathrm{~Hz}, \mathrm{H}-3), 7.21-7.35$ (5H, m, Ar.H).

\subsubsection{Formation of Methyl Ester of 1}

$\mathbf{1}(8.8 \mathrm{mg})$ was added trimethylsilyldiazomethane (10\% in hexane) $2 \mathrm{~mL}$, and the reaction mixture was stirred at room temperature overnight. The reaction mixture was evaporated under reduced pressure, and the residue was purified by $\mathrm{HPLC}$ using $\mathrm{MeOH}-\mathrm{H}_{2} \mathrm{O}$ (60:40) as the eluent to afford methyl ester $(6.5 \mathrm{mg})$ as a pale yellow oil.

Methyl ester of 1: Pale yellow oil; $[\alpha]_{\mathrm{D}}^{22}-7.9$ (c 0.25, MeCN); HRFABMS $m / z 243.1597[\mathrm{M}+\mathrm{H}]^{+}$ (calcd for $\mathrm{C}_{13} \mathrm{H}_{23} \mathrm{O}_{4}:$ 243.1597). ${ }^{1} \mathrm{H}$ NMR $\delta$ ppm $\left(600 \mathrm{MHz}\right.$ in $\left.\mathrm{CDCl}_{3}\right): 1.61(3 \mathrm{H}, \mathrm{s}, \mathrm{H}-12), 1.68$ (3H, s, H-11), 2.19 (1H, ddd, J 14.4, 7.2, 7.2 Hz, H-8A), 2.42 (1H, m, H-5A), 2.45 (1H, m, H-8B), 2.47 (1H, m, H-5B), $3.32(1 \mathrm{H}, \mathrm{ddd}, J$ 9.6, 7.8, $7.8 \mathrm{~Hz}, \mathrm{H}-2), 3.64\left(3 \mathrm{H}, \mathrm{s}, \mathrm{OCH}_{3}\right), 3.73(2 \mathrm{H}, \mathrm{m}, \mathrm{H}-6), 4.08(1 \mathrm{H}, \mathrm{d}, J 17.6 \mathrm{~Hz}$, H-7A), 4.10 (1H, d, J 17.6 Hz, H-7B), 5.04 (1H, dd, J 7.2, 7.2 Hz, H-9), 5.56, (1H, d, J 10.2 Hz, H-3).

\subsubsection{Methanolysis of $2-4$}

To a solution of $2(3.2 \mathrm{mg})$ in $\mathrm{MeOH}(0,5 \mathrm{mg})$ was added concd $\mathrm{H}_{2} \mathrm{SO}_{4}(0.01 \mathrm{~mL})$, and the reaction mixture was left at room temperature for $1 \mathrm{hr}$. The mixture was diluted with water, and extracted with $\mathrm{CH}_{2} \mathrm{Cl}_{2}$, and the extract was evaporated under reduced pressure, and then the residue was purified by HPLC using $\mathrm{MeOH}-\mathrm{H}_{2} \mathrm{O}(60: 40)$ as the eluent to afford methyl ester $(0.8 \mathrm{mg})$ as a pale yellow oil.

Using the same procedure as above with 2 , a solution of $3(3.3 \mathrm{mg})$ in $\mathrm{MeOH}(0.5 \mathrm{~mL})$ was treated with concd $\mathrm{H}_{2} \mathrm{SO}_{4}(0.01 \mathrm{~mL})$, and purified by $\mathrm{HPLC}$ using $\mathrm{MeOH}-\mathrm{H}_{2} \mathrm{O}(60: 40)$ as the eluent to afford methyl ester $(0.8 \mathrm{mg})$.

Using the same procedure as above with 2, a solution of $4(2.4 \mathrm{mg})$ in $\mathrm{MeOH}(0.5 \mathrm{~mL})$ was treated with concd $\mathrm{H}_{2} \mathrm{SO}_{4}(0.01 \mathrm{~mL})$, and purified by $\mathrm{HPLC}$ using $\mathrm{MeOH}-\mathrm{H}_{2} \mathrm{O}(60: 40)$ as the eluent to afford methyl ester $(0.7 \mathrm{mg})$.

\section{Conclusions}

In this study, new carboxylic acids designated as sterepinic acids A-C (1-3) and dihydro-1,5secovibralactone (4), have been isolated from a strain of Stereum sp. derived from marine sponge. 
Their absolute configurations were established by the application of the PGME method to 1 and the chemical transformation of $\mathbf{2}-\mathbf{4}$.

In the screening for the search of the seeds of antitumor agents, these compounds did not exhibit significant cytotoxic activity against three cancer cell lines.

Supplementary Materials: The following are available online, Table S1: Spectral data including 2D NMR data for 1, Table S2: Spectral data including 2D NMR data for 2, Table S3: Spectral data including 2D NMR data for 3, Table S4: Spectral data including 2D NMR data for 4, Figure S1: ${ }^{1} \mathrm{H}$ NMR spectra of 1 in $\mathrm{CDCl}_{3}$, Figure S2: ${ }^{13} \mathrm{C}$ NMR spectra of $\mathbf{1}$ in $\mathrm{CDCl}_{3}$, Figure S3: ${ }^{1} \mathrm{H}^{-1} \mathrm{H}$ COSY of 1, Figure S4: NOESY of 1, Figure S5: HMQC of $\mathbf{1}$, Figure S6: HMBC of 1, Figure S7: ${ }^{1} \mathrm{H}$ NMR spectrum of 2 in $\mathrm{CDCl}_{3}$, Figure S8: ${ }^{13} \mathrm{C}$ NMR spectrum of 2 in $\mathrm{CDCl}_{3}$, Figure S9: ${ }^{1} \mathrm{H}-{ }^{1} \mathrm{H}$ COSY of 2, Figure S10: NOESY of 2, Figure S11: HMQC of 2, Figure S12: HMBC of 2, Figure S13: ${ }^{1} \mathrm{H}$ NMR spectrum of 3 in $\mathrm{CDCl}_{3}$, Figure S14: ${ }^{13} \mathrm{C}$ NMR spectrum of 3 in $\mathrm{CDCl}_{3}$, Figure S15: ${ }^{1} \mathrm{H}-{ }^{1} \mathrm{H}$ COSY of 3, Figure S16: NOESY of 3, Figure S17: HMQC of 3, Figure S18: HMBC of 3, Figure S19: ${ }^{1} \mathrm{H}$ NMR spectrum of 4 in $\mathrm{CDCl}_{3}$, Figure S20: ${ }^{13} \mathrm{C}$ NMR spectrum of 4 in $\mathrm{CDCl}_{3}$, Figure S21: ${ }^{1} \mathrm{H}-{ }^{1} \mathrm{H}$ COSY of 4, Figure S22: NOESY of 4, Figure S25: HMQC of 4, Figure S24: HMBC of 4, Figure S25: ${ }^{1} \mathrm{H}$ NMR spectra of 1 a in $\mathrm{CDCl}_{3}$, Figure S26: ${ }^{1} \mathrm{H}$ NMR spectra of $\mathbf{1 b}$ in $\mathrm{CDCl}_{3}$, Figure S27: ${ }^{1} \mathrm{H}$ NMR spectra of methyl ester of $\mathbf{1}$ in $\mathrm{CDCl}_{3}$.

Author Contributions: Conceived and designed the experiments: T.Y., M.M., M.S., M.H., T.K.; Performed the experiments: T.Y., M.M., M.S., M.H.; Analyzed the data: T.Y.; Wrote the paper: T.Y.

Funding: This research received no external funding.

Acknowledgments: We thank Y. Endo (Kanazawa University) for supply of the cancer cells. We are grateful to M. Fujitake and K. Minoura of this university for MS and NMR measurements, respectively.

Conflicts of Interest: The authors declare no conflict of interest.

\section{References}

1. Muroga, Y.; Yamada, T.; Numata, A.; Tanaka, R. Chaetomugilins I-O, new potent cytotoxic metabolites from a marine-fish-derived Chaetomium species. Stereochemistry and biological activities. Tetrahedron 2009, 65, 7580-7586. [CrossRef]

2. Yamada, T.; Kitada, H.; Kajimoto, T.; Numata, A.; Tanaka, R. The relationship between the CD Cotton effect and the absolute configuration of FD-838 and its seven stereoisomers. J. Org. Chem. 2010, 75, 4146-4153. [CrossRef] [PubMed]

3. Yamada, T.; Kikuchi, T.; Tanaka, R.; Numata, A. Halichoblelides B and C, potent cytotoxic macrolides from a Streptomyces species separated from a marine fish. Tetrahedron Lett. 2012, 53, 2842-2846. [CrossRef]

4. Kitano, M.; Yamada, T.; Amagata, T.; Minoura, K.; Tanaka, R.; Numata, A. Novel pyridinopyrone sesquiterpene type pileotin produced by a sea urchin-derived Aspergillus sp. Tetrahedron Lett. 2012, 53, 4192-4194. [CrossRef]

5. Yamada, T.; Mizutani, Y.; Umebayashi, Y.; Inno, N.; Kawashima, M.; Kikuchi, T.; Tanaka, R. A novel ketoaldehyde decalin derivative, produced by a marine sponge-derived Trichoderma harzianum. Tetrahedron Lett. 2014, 55, 662-664. [CrossRef]

6. Yamada, T.; Umebayashi, Y.; Kawashima, M.; Sugiura, Y.; Kikuchi, T.; Tanaka, R. Determination of the chemical structures of tandyukisins B-D, isolated from a marine sponge-derived fungus. Mar. Drugs 2015, 13, 3231-3240. [CrossRef] [PubMed]

7. Suzue, M.; Kikuchi, T.; Tanaka, R.; Yamada, T. Tandyukisins E and F, novel cytotoxic decalin derivatives isolated from a marine sponge-derived fungus. Tetrahedron Lett. 2016, 57, 5070-5073. [CrossRef]

8. Yamada, T.; Suzue, M.; Arai, T.; Kikuchi, T.; Tanaka, R. Trichodermanins C-E, new diterpenes with a fused 6-5-6-6 ring system produced by a marine sponge-derived fungus. Marine Drugs 2017, 15, 169. [CrossRef] [PubMed]

9. Liu, D.Z.; Wang, F.; Liao, T.G.; Tang, J.G.; Steglich, W.; Zhu, H.J.; Liu, J.K. Vibralactone: A lipase inhibitor with an unusual fused $\beta$-lactone produced by cultures of the basidiomycete. Boreostereum vibrans. Org. Lett. 2006, 8, 5749-5752. [CrossRef] [PubMed]

10. Jiang, M.Y.; Wang, F.; Yang, X.L.; Fang, L.Z.; Dong, Z.J.; Zhu, H.J.; Liu, J.K. Derivatives of vibralactone from cultures of the basidiomycete Boreostereum vibrans. Chem. Pharm. Bull. 2008, 56, 1286-1288. [CrossRef] [PubMed] 
11. Jiang, M.Y.; Zhang, L.; Dong, Z.J.; Yang, Z.L.; Leng, Y.; Liu, J.K. Vibralactones D-F from cultures of the basidiomycete Boreostereum vibrans. Chem. Pharm. Bull. 2010, 58, 113-116. [CrossRef] [PubMed]

12. Ding, J.H.; Feng, T.; Li, Z.H.; Li, L.; Liu, J.K. Twelve new compounds from the basidiomycete Boreostereum vibrans. Nat. Prod. Bioprospect. 2012, 2, 200-205. [CrossRef]

13. Wang, G.Q.; Wei, K.; Feng, T.; Li, Z.H.; Zhang, L.; Wang, Q.A.; Liu, J.K. Vibralactones G-J from cultures of the basidiomycete Boreostereum vibrans. J. Asian Nat. Prod. Res. 2012, 14, 115-120. [CrossRef] [PubMed]

14. Wang, G.Q.; Wei, K.; Li, Z.H.; Feng, T.; Ding, J.H.; Wang, Q.A.; Liu, J.K. Three new compounds from the cultures of basidiomycete Boreostereum vibrans. J. Asian Nat. Prod. Res. 2013, 15, 950-955. [CrossRef] [PubMed]

15. Chen, H.P.; Zhao, Z.Z.; Yin, R.H.; Yin, X.; Feng, T.; Li, Z.H.; Wei, K.; Liu, J.K. Six new vibralactone derivatives from cultures of the fungus Boreostereum vibrans. Nat. Prod. Bioprospect. 2014, 4, 271-276. [CrossRef] [PubMed]

16. Yabuuchi, T.; Kusumi, T. Phenylglycine Methyl Ester, a Useful Tool for Absolute Configuration Determination of various chiral carboxylic acids. J. Org. Chem. 2000, 65, 397-404. [CrossRef] [PubMed]

17. Zhao, P.J.; Yang, Y.L.; Du, L.; Liu, J.K.; Zeng, Y. Elucidating the biosynthetic pathway for vibralactone: A pancreatic lipase inhibitor with a fused bicyclic $\beta$-lactone. Angew. Chem. Int. Ed. 2013, 52, 2298-2302. [CrossRef] [PubMed]

Sample Availability: Samples of the compounds are available from the authors. 